\title{
PENERAPAN METODE PEMBELAJARAN “ACTIVE LEARNING-SMALL GROUP DISCUSSION” DI PERGURUAN TINGGI SEBAGAI UPAYA PENINGKATAN PROSES PEMBELAJARAN
}

\author{
Endah Syamsiyati N.J \\ Universitas Islam Negeri Sunan Kalijaga Yogyakarta \\ endahsyamsi@gmail.com
}

\begin{abstract}
The active learning approach that is carried out in the subject of Student Development in the Faculty of Islamic Sciences majoring in PAI at the Islamic University of Indonesia in the 4th semester, aims to improve student learning activeness with nonmonotonous learning strategies. With this learning method, students can actively explore themselves by finding the main ideas in solving a problem, or students can apply what is learned in real life. Several learning methods can be used as alternatives to increase student activity during the learning process, one of them is "Active Learning Methods-Small Group Discussion". This study uses a qualitative descriptive analysis by collecting data through observation and documentation. The results of this research method of active learning with a group discussion or small group discussion can increase learning activeness involving fourth-semester students of class D in the subject of the development of PAI FIAI UII Yogyakarta students in terms of the theories put forward by experts.
\end{abstract}

Keywords: Active Learning, Small Group Discussion (SGD) Method

\begin{abstract}
Abstrak: Pendekatan active learning yang dilaksanakan pada pembelajaran mata kuliah Perkembangan Peserta Didik di Fakultas Ilmu Agama Islam jurusan PAI Universitas Islam Indonesia semester 4, bertujuan untuk meningkatkan keaktifan belajar mahasiswa dengan strategi pembelajaran yang tidak monoton. Dengan metode pembelajaran tersebut mahasiswa dapat secara aktif mengeksplorasi diri dengan menemukan ide-ide pokok dalam memecahkan suatu persoalan, atau mahasiswa dapat mengaplikasikan apa yang dipelajari dalam kehidupan nyata. Ada beberapa meode pembelajaran yang dapat digunakan sebagai alternatif untuk meningkatkan keaktifan mahasiswa selama proses pembelajaran, salah satunya yaitu dengan "Metode Pembelajaran Aktif-Small Group Discussion". Penelitian ini menggunakan analisis deskiptif kualitatif dengan pengumpulan data melalui observasi dan dokumentasi. Hasil penelitian ini metode active learning dengan diskusi kelompok atau small group discussion dapat meningkatkan keaktifan belajar yang melibatkan mahasiswa semester 4 kelas D mata kuliah perkembangan peserta didik jurusan PAI FIAI UII Yogyakarta yang ditinjau dari teori-teori yang dikemukakan oleh para ahli.
\end{abstract}

Kata Kunci: Pembelajaran Aktif, Metode Small Group Discussion (SGD)

Fondatia : Jurnal Pendidikan Dasar

Volume 3, Nomor 2, September 2019; 19-34

https://ejournal.stitpn.ac.id/index.php/fondatia 


\section{PENDAHULUAN}

Pendidik yang profesional dapat terlihat dari keahliannya di dalam menyampaikan materi pembelajaran kepada peserta didik. Dalam menyampaikan materi yang efektif dan efisien, seorang pendidik perlu mengenal berbagai jenis metode pembelajaran sehingga dapat memilih metode yang paling tepat untuk mengajarkan suatu bidang studi tertentu. Pendidik yang profesional tidak hanya berpikir tentang apa saja yang akan diajarkan, tetapi juga tentang siapa yang menerima pelajaran, apa makna dari belajar, dan bagaimana kemampuan dari peserta didik dalam mengikuti proses pembelajaran. ${ }^{1}$ Seorang guru atau dosen dalam proses pembelajaran memiliki peran yang paling penting atau sentral dalam tercapainya tujuan pembelajaran yaitu sebagai perancang sekaligus sebagai pengelola proses pembelajaran tersebut. ${ }^{2}$

Implementasi dalam kegiatan pembelajaran mengenal banyak istilah untuk menggambarkan bagaimana cara mengajar yang akan dilakukan oleh pendidik. Berbagai macam strategi ataupun metode pembelajaran bertujuan meningkatkan kualitas pembelajaran peserta didik untuk menjadi lebih baik. Dalam mencapai tujuan pembelajaran, pendidik harus memahami betul metode pembelajaran yang akan diterapkannya. Pemilihan metode pembelajaran yang tepat akan berdampak pada tingkat penguasaan materi atau prestasi belajar bagi peserta didiknya.

Proses pembelajaran yang terjadi saat ini sering kali bersifat seadanya, formalitas, dan kurang bermakna. Penelitian yang dilakukan oleh Semiawan, menyatakan bahwa sudah terjadi formalisasi proses pembelajaran di PT. Dosen menjadi peran utama di kelasnya dalam menyajikan, menjelaskan, menganalisis dan mempertanggungjawabkann "body of material" kuliah. Mahasiswa hanya mengikuti secara pasif dan menghafalkan bahan kuliah untuk diterima apa adanya saat ujian. ${ }^{3}$

Rendahnya inisiatif mahasiswa untuk berpartisipasi secara langsung merupakan salah satu dampak dari proses pembelajaran komunikasi yang searah yang berlangsung dalam proses perkuliahan di perguruan tinggi. Selain itu, mahasiswa

1 Nurdyansyah \& Eni Faiyatul Fahyuni, Inovasi Model Pembelajaran Sesuai Kurikulum 2013, (Sidoarjo: Nizamia Learning Center Sidoarjo, 2016), hlm. 4.

2Sohibun, Febriani, Y., \& Maisaroh, I. (2017). Peranan Mata Kuliah Profesi Kependidikan dan Microteaching terhadap Kompetensi Profesional Mahasiswa PPL Fisika. Tadris: Jurnal Keguruan Dan Ilmu Tarbiyah, 2(1), 53-61.

3 Ali Muhtadi, dalam artikel yang berjudul Model Pembelajaran "Active Learning” dengan Metode Kelompok untuk Meningkatkan Kualitas Proses Pembelajaran di Perguruan Tinggi, hlm. 2 
cukup pasif untuk berpartisipasi dalam proses perkuliahan karena kurang adanya kondisi yang memungkinkan mahasiswa dalam membangun pengetahuannya sendiri. Keberanian dari mahasiswa untuk bertanya dan mengajukan pendapat, sepertinya telah didoktrin oleh tradisi dosen yang mendominasi perkuliahan. Berdasarkan analisis permasalahan tersebut, penulis tertarik untuk melakukan penelitian dengan strategi pembelajaran "active learning" dengan metode small group discussion (SGD) sebagai salah satu alternatif yang dapat meningkatkan kualitas prosess pembelajaran di Perguruan Tinggi. Strategi pembelajaran "Active learning” dengan metode small group discussion (SGD) dianggap tepat dan relevan dengan tujuan dalam peningkatan kualitas proses perkuliahan, serta dapat meningkatkan keaktifan mahasiswa dalam proses pembelajaran. Pendidikan dapat terlaksana melalui adanya proses belajar mengajar bukan hanya di dalam kelas saja tetapi dapat terlaksana di luar kelas. ${ }^{4}$

\section{KAJIAN PUSTAKA}

\section{Metode Pembelajaran}

Metode yaitu cara kerja bersistem yang dapat mempermudah pelaksanaan suatu kegiatan dalam mencapai tujuan yang sudah ditentukan ${ }^{5}$. Metode pembelajaran merupakan seluruh perencanaan maupun langkah-langkah dalam kegiatan pembelajaran termasuk cara penilaian yang akan dilaksanakan. Metode pembelajaran dapat diartikan sebagai suatu proses yang teratur dalam berlangsungnya suatu pembelajaran. ${ }^{6}$

Metode pembelajaran mempunyai pengaruh besar dalam meningkatkan prestasi belajar siswa atau mahasiswa di dalam proses pembelajaran di kelas. Dosen dapat menggunakan bermacam-macam metode pembelajaran yang sesuai dengan kebutuhan mahasiswa di kelas, metode pengajaran yang digunakan dosen yaitu metode ceramah (Preaching Method), metode diskusi (Discussion method),

${ }^{4}$ Abdurrahman. (2017). Efektivitas dan Kendala Pembelajaran Sains Berbasis Inkuiri terhadap Capaian Dimensi Kognitif Siswa : Meta Analisis. Tadris: Jurnal Keguruan Dan Ilmu Tarbiyah, 2(1), 19 .

${ }^{5}$ Kamus Besar Bahasa Indonesia

${ }^{6}$ Suyono, Belajar dan Pembelajaran: Teori dan Konep Dasar (Bandung: PT Remaja Rosdakarya, 2012), hlm. 19. 
metode pemecahan masalah (Problem solving method), metode percobaan (Experimental method), metode perancangan (projeck method), metode latihan keterampilan (Drill method). Dari berbagai macam metode pembelajaran tersebut, setiap metode pembelajarannya mempunyai peranan atau kelebihan masingmasing, maka dari itu kemampuan dosen atau guru diperlukan dalam menyesuaikan metode pembelajaran dalam proses pembelajaran di kelas. ${ }^{7}$

\section{Active Learning}

a. Pengertian

Pembelajaran "active learning" telah ada pada masa Socrates yang merupakan salah satu pencetus utama di antara para pendidik progresif seperti John Dewey yang beranggapan bahwa secara alami belajar merupakan proses yang aktif.

Active learning atau cara belajar siswa aktif, dapat diartikan sebagai pembelajaran yang mengarah pada pengoptimalisasian yang melibatkan segi intelektual dan segi emosional siswa dalam proses pembelajaran yang mengarah pada pengetahuan, keterampilan, sikap dan nilai. ${ }^{8}$

Keterlibatan peserta didik secara aktif dalam proses pengajaran yang diharapkan yaitu keterlibatan siswa secara mental (intelektual dan emosional) dan secara keaktifan fisik. Sehingga peserta didik benar benar berperan serta dan berpartisipasi aktif dalam proses pengajaran, dengan menempatkan kedudukan peserta didik sebagai subyek, dan sebagai pihak yang penting dan utama dalam kegiatan belajar mengajar.

Menurut Silberman yang dikutip oleh Ali Muhtadi, bahwa pembelajaran aktif:

What I hear, I forget; What I see, I remember a litle; What I hear, see and ask questions abaut or discuss with someone else, I begin to Understand; What I hear, see, discuss, and do, I acquire knowledge and skill What I teach to another, I master. ${ }^{10}$

${ }^{7}$ Mardiah Kalsum Nasution, 'Penggunaan Metode Pembelajaran Dalam Peningkatan Hasil Belajar Siswa, dalam Jurnal Ilmiah Bidang Pendidikan, Vol. 11 No. 1, April 2017.

${ }^{8}$ Mudjiono, Dimyati, Belajar dan Pembelajran, (Jakarta:PT Rineka Cipta, 2013), hlm. 115.

${ }^{9}$ Ahmad rohani, Pengelolaban Pengajaran, (Jakarta: P'T Rineka cipta, 2010),hlm. 61-62

${ }^{10}$ Ali Muhtadi..., hlm.3. 
Kutipan diatas menerangkan bahwa pentingnya pengembangan strategi "active learning" dalam proses pembelajaran di kelas, sehingga tercapai tujuan-tujuan pembelajaran secara efektif dan efisien. Melalui keaktifan mendengar, menyimak, bertanya atau berdiskusi, dan mengaplikasikan pengetahuan yang didapat dengan cara mengajarkannya kepada orang lain, peserta didik akan mampu memahami materi pelajaran yang dikaji.

b. Karakteristik active learning

Dalam active learning ada beberapa indikator yang mempengaruhinya secara optimal antara lain:

(1) Pembelajaran lebih berpusat pada siswa, sehingga siswa berperan lebih aktif dalam mengembangkan pengetahuan serta siswa berperan pada perencanaan, pelaksanaan dan penilaian proses belajar dan pengalaman siswa lebih di utamakan dalam memutuskan titik tolak kegiatan. (2) Guru sebagai pembimbing terjadinya pengalaman belajar, guru bukan hanya sebagai satusatunya sumber informasi, guru merupakan salah satu sumber belajar yang memberikan peluang bagi siswa agar dapat meperoleh pengetahuan atau keterampilan melalui usaha sendiri, dapat mengembangkan motivasi dari dalam dirinya, dan dapat mengembangkan pengalaman. (3) Tujuan kegiatan bukan hanya untuk sekedar mengajar standar akademis, melainkan kegiatan di tekankan untuk mengembangkan kemampuan siswa secara utuh dan seimbang. (4) Pengelolaan kegiatan pembelajaran lebih ditekankan pada kreatiftas para siswa, dan memperhatikan kemajuan siswa untuk menguasai pengetahuan dengan mantap. (5) Penilaian dilaksanakan untuk mengamati dan mengatur kegiatan siswa serta mengukur keterampilan yang tidak dikembangkan misalnya keterampilan berbahasa, keterampilan sosial dan keterampilan lainnya serta mengukur hasil belajar siswa. ${ }^{11}$

\section{Small Group Discussion (SGD)}

a. Pengertian

Pembelajaran dengan metode Small Group Discussion adalah serangkaian kegiatan belajar yang dilakukan oleh peserta didik dalam kelompok-kelompok

${ }^{11}$ Dimyati, mujiono, belajar dan pembelajaran, (Jakarta: PT. Rineka cipta, 2013), hlm. 120. 
tertentu untuk mencapai tujuan pembelajaran yang telah ditentukan. Ada empat unsur penting dalam pembelajaran Small Group Discussion: 1. adanya peserta, 2. adanya aturan, 3. upaya belajar setiap kelompok dan, 4. tujuan yang akan dicapai. ${ }^{12}$

Metode pembelajaran Small Group Discussion (SGD) dimulai dengan guru menyajikan permasalahan secara umum, kemudian masalah tersebut dibagi per sub bab yang harus dipecahkan setiap kelompok-kelompok kecil, setelah selesai diskusi, perwakilan dari tiap kelompok menyajikan hasil diskusinya masing-masing.

\section{b. Tujuan SGD}

1) Mahasiswa bisa saling memecahkan masalah-masalah yang terjadi di lingkungan sekitar mereka, baik dalam kehidupan sehari- hari maupun permasalahan yang terjadi di dalam kelas.

2) Mahasiswa dapat berdiskusi dan saling mengoreksi satu sama lain mengenai pemahaman mereka dalam proses pembelajaran di kelas, sehingga mahasiswa bisa memahami dengan lebih baik. ${ }^{13}$

c. Kelebihan SGD

Kelebihan dari metode pembelajaran Small Group Discussion adalah:

1) Membentuk kreatifitas peserta didik dalam bentuk ide, gagasan, dan terobosan baru dalam pemecahan suatu masalah

2) Mengembangkan sikap menghargai pendapat orang lain

3) Memperluas wawasan

4) Membiasakan untuk musyawarah dalam memecahkan suatu masalah. ${ }^{14}$

d. Langkah penerapan metode SGD

Langkah-langkah dalam penerapan metode SGD sebagai berikut:

1) Membagi kelas menjadi beberapa kelompok kecil

${ }^{12}$ Ismail, Strategi Pembelajaran Agama Islam Berbasis PAIKEM, (Semarang:Rasail, 2011), hlm. 8788.

${ }^{13}$ Nur Wahyuning Sulistyowati, "Implementasi Small Group Discussion Dan Collaborative Learning Untuk Meningkatkan Prestasi Belajar Mahasiswa Program Studi Pendidikan Akuntasi IKIP PGRI Madiun”, dalam Jurnal Akuntasi dan Pendidikan, Vol. 5 (2), Oktober 2016.

${ }^{14}$ Syaiful Bahri Djamrah dan Aswan Zain, Strategi Belajr Mengajar, Jakarta: Rineka Cipta, 2006), hlm. 99 
2) Memberi soal studi kasus yang sudah disiapkan pendidik

3) Memberi Intruksi kepada setiap kelompok untuk mendiskusikan jawaban soal tersebut

4) Pastikan setiap anggota kelompok berpartisipasi aktif dalam diskusi

5) Memberi Instruksi pada setiap kelompok untuk menunjuk satu juru bicara untuk menyajikan hasil diskusinya

6) Klarifikasi, pendidik memberikan penyimpulan dan tindak lanjut. ${ }^{15}$

\section{Strategi pembelajaran Active Learning dengan metode Small Group Discussion}

Strategi pembelajaran "Active Learning” dengan metode diskusi merupakan strategi pembelajaran yang dikembangkan dari prinsip teori kerja otak, teori belajar konstruktivistik, dan teori belajar kolaboratif atau kooperatif. Pembelajaran active menekankan pada aktifitas kerja dan partisipasi aktif mahasiswa dari segi intelektual dan emosional secara optimal melalui aktivitas belajar di dalam tim dan antar tim untuk memperoleh pemahaman materi yang lebih bermakna. Keaktifan dari mahasiswa terlihat dari proses mendengarkan, mencatat bagian-bagian penting dari materi, menyimak materi dan merefleksikan setiap materi yang dibahas dalam proses pembelajaran di kelas. Sedangkan peran aktif dari mahasiswa dalam suatu tim berupa kegiatan eksplorasi dengan proses interaksi antar tim dalam suatu pembelajaran sehingga mahasiswa diharapkan bisa mengkonstruk pengetahuan yang dengan menggunakan kata-kata yang mereka pahami, maka dari itu mahasiswa akan lebih mudah dalam memahami pengetahuan yang diperolehnya dan lebih bermakna

\section{Keaktifan belajar}

Dalam mengikuti proses pembelajaran, pendidik harus mengetahui sejauh mana keaktifan peserta didik. Kriteria tentang keaktifan belajar di antaranya yaitu:

a. Turut serta dalam mengerjakan tugas belajarnya

b. Melibatkan diri dalam memecahkan masalah

${ }^{15}$ Ismail..., hlm.88 
c. Bertanya kepada guru atau teman lainnya ketika tidak memahami persoalan yang dihadapinya

d. Mencari berbagai informasi yang diperlukan

e. Diskusi dengan teman kelompok sesuai petunjuk guru

f. Melatih diri untuk memecahkan persoalan atau permasalahan

g. Mengaplikasikan apa yang diperolehnya dalam menyelesaikan tugas atau persoalan yang dihadapi. ${ }^{16}$

Pengelompokan keaktifan peserta didik menurut Munir dibagi menjadi beberapa aspek, antara lain:

a. aktif secara jasmani seperti pengindraan ( seperti: mendengar, melihat, mencium, merasa, dan meraba atau melakukan keterampilan jasmaniah)

b. aktif berpikir melalui tanya jawab ( seperti: mengolah dan mengemukakan ide, berpikir logis, sistematis ) dan

c. aktif secara sosial seperti aktif berinteraksi atau bekerjasama dengan orang lain.$^{17}$

\section{METODE PENELITIAN}

Penelitian ini bersifat field research (penelitian lapangan), karena peneliti langsung menggali data di lapangan secara real dan sesuai fakta di lapangan. Di samping itu, peneliti mengumpulkan data sebanyak-banyaknya yang berkaitan tentang pelaksanaan metode active learning dalam pembelajaran di Perguruan Tinggi pada mahasiswa UII Fakultas Ilmu Agama Islam jurusan Pendidikan Agama Islam kelas D semester 4 mata kuliah Perkembangan Peserta Didik. Jenis pendekatan penelitian ini bersifat kualitatif, yaitu penelitian yang prosedurnya menghasilkan data deskriptif yang berupa kata-kata tertulis atau lisan dari orang-orang dan perilaku yang diamati.

Metode Pengumpulan data yang digunakan penulis yaitu dengan menggunakan observasi dan Dokumentasi. Penulis melakukan pengamatan langsung yaitu dengan kegiatan pengumpulan data terhadap kondisi lingkungan obyek penelitian. Metode observasi ini memperoleh data mengenai pelaksanaan metode

${ }^{16}$ Sudjana, Nana, Metode Statistika, Edisi Ke 6, Bandung: Tarsito, 2005.

${ }^{17}$ Munir, Kurikulum Berbasis Teknologi Informasi dan Komunikasi, Bandung: Alfabeta, 2008. 
pembelajaran active learning dalam meningkatkan keaktifan dan pemahaman mahasiswa. Dalam metode dokumentasinya penulis gunakan untuk memperoleh data tentang letak geografis, sejarah berdirinya, visi dan misi dan tujuan, sarana dan prasarana, dan struktur organisasi yang dapat mendukung dalam penelitian di FIAI UII.

Dalam menganalisis data penulis menggunakan metode deskriptif kualitatif, yaitu data yang diperoleh digambarkan dengan kata-kata atau kalimat menurut masing-masing kategori untuk penarikan kesimpulan Untuk menganalisis data ini penulis menggunakan analis deduktif. Analisis ini cara kerjanya adalah dilihat dari teori kemudian dikaitkan dengan fakta dan kenyataan yang ada di lapangan

\section{HASIL DAN PEMBAHASAN}

Berdasarkan deskripsi data yang telah penulis paparkan dengan data-data yang didapatkan dari hasil observasi, wawancara, dan dokumentasi dapat dianalisis bahwa terdapat beberapa hal yang mempengaruhi pelaksanaan metode active learning dalam meningkatkan pemahaman dan keaktifan mahasiswa dalam pembelajaran di kelas pada mata kuliah Perkembangan Peserta Didik kelas D semester 4 jurusan PAI FIAI UII.

Data yang penulis peroleh dari pengamatan pelaksanaan pembelajaran mata kuliah Perkembangan Peserta Didik yaitu bentuk pengajaran dikelasnya dengan menggunakan metode active learning berupa diskusi kelompok atau SGD yang bertujuan untuk menumbuhkan pemahaman mahasiswa tentang materi yang terdapat dalam mata kuliah perkembangan peserta didik tersebut.

Adapun tujuan dari penggunaan metode active learning yaitu mahasiswa mampu memecahkan masalah dengan cara kerjasama kelompoknya secara demokratis, sehingga mahasiswa mempunyai kecakapan yang sesuai dengan kebutuhan mahasiswa yaitu mengenai pemahaman materi perkuliahan dan dapat mengamalkannya dalam kehidupan sehari-hari. Selain itu mahasiswa dapat bertukar pikiran dengan teman sekelompoknya dan adanya saling menghargai satu sama lain dalam memberikan suatu pendapat mengenai persoalan atau permasalahan yang ada. 
Dari data yang telah dijelaskan sebelumnya tentang pelaksanaan metode active learning dengan SGD yaitu ketika diskusi berlangsung mahasiswa bersegera membentuk kelompok sesuai arahan dari dosen, membaca materi yang telah dibagi sesuai kelompoknya serta merangkum materi atau menuliskan poin-poin penting untuk dipresentasikan di depan kelas bertujuan agar teman-teman yang lain dapat mendengarkan dan memperhatikan hasil diskusi dari kelompok lain. Dalam penggunaan metode SGD ini mempunyai tujuan untuk meningkatkan kualitas berfikir mahasiswa yang dibangun dalam ruangan kelas. Sedangkan aktivitas sosialnya dikembangkan dalam bentuk kerja sama antara mahasiswa yang satu dengan mahasiswa lainnya yang lebih mampu di bawah bimbingan dosen atau pendidik.

Dalam meningkatkan pemahaman mahasiswa tentang materi, dosen menggunakan metode yang dirasakan cocok dan sesuai dengan kondisi mahasiswa tersebut. Mahasiswa aktif dalam pembelajaran di kelas dan mendominasi kelas, sehingga pemahaman mereka meningkat sejak dosen menggunakan metode tersebut. Hal tersebut ditandai dengan keaktifan mahasiswa yang rata-rata pendiam dan malas untuk belajar di kelas menjadi lebih semangat dan tertarik untuk belajar dengan teman sekelompoknya kondisi tersebut sesuai dengan teori Piaget yaitu kegiatan pembelajaran yang harus melibatkan partisipasi peserta didik. Menurut teori ini pengetahuan tidak hanya sekedar dipindahkan secara verbal tetapi harus dikonstruksi peserta didik.

Pemahaman mahasiswa tidak hanya dari pengetahuan dan wawasannya saja, akan tetapi mereka mampu bersikap sosial dengan teman yang lainnya dalam membangun kerjasama tim, dan saling belajar dan mengutarakan pendapatnya masing-masing. Secara tidak langsung mereka sudah melakukan interaksi dengan melibatkan sikap sosial didalamnya.

Dalam pembelajaran dengan metode SGD (small Group Discussion) Dosen mata kuliah Perkembangan peserta didik membuat kerangka kegiatan pembelajaran dengan tujuan supaya menambah keaktifan mahasiswa dalam proses belajar, kerangka kegiatan tersebut tercantum sebagai berikut: 


\begin{tabular}{|c|c|}
\hline No. & \\
\hline 1 & $\begin{array}{l}\text { Kegiatan Awal } \\
\text { a. Mahasiswa menjawab salam dan berdoa sebelum memulai } \\
\text { perkuliahan. } \\
\text { b. Mahasiswa memberitahukan mengenai kehadirannya di dalam } \\
\text { perkuliahan. } \\
\text { c. Mahasiswa menjawab pertanyaan dari dosen berkaitan dengan } \\
\text { materi yang dipelajari pada pertemuan sebelumnya. } \\
\text { d. Mahasiswa mendengarkan dan memahami tujuan pembelajaran } \\
\text { yang disampaikan dosen. }\end{array}$ \\
\hline 2 & $\begin{array}{l}\text { Kegiatan Inti } \\
\text { a. Mahasiswa mendengarkan penjelasan tentang materi } \\
\text { perkuliahan. } \\
\text { b. Mahasiswa dipersilakan untuk melakukan tanya jawab } \\
\text { c. Mahasiswa melakukan group disscussion mengenai materi ciri-ciri } \\
\text { perkembangan dan tugas-tugas perkembangan pada masa anak } \\
\text { TK dan SD } \\
\text { d. Mahasiswa memperhatikan arahan dosen ketika diskusi } \\
\text { berlangsung. } \\
\text { e. Mahasiswa memperhatikan dosen ketika memberi penguatan } \\
\text { terhadap pernyataan-pernyataan mahasiswa. }\end{array}$ \\
\hline 3 & $\begin{array}{l}\text { Penutup } \\
\text { a. Evaluasi dilakukan dalam bentuk penugasan. } \\
\text { b. Mahasiswa membuat kesimpulan bersama dosen. } \\
\text { c. Mahasiswa melakukan refleksi hasil perkuliahan. } \\
\text { d. Penugasan: tiap mahasiswa membuat portofolio } \\
\text { e. Mahasiswa memperhatikan motivasi dari dosen untuk selalu } \\
\text { melakukan yang terbaik dalam melakukan segala sesuatu } \\
\text { terlebih dalam melakukan proses pendidikan. } \\
\text { f. Perkuliahan ditutup dengan mahasiswa mengucapkan hamdalah } \\
\text { dan menjawab salam dari dosen. }\end{array}$ \\
\hline
\end{tabular}


Bertambahnya indikator keaktifan belajar mahasiswa dapat di ukur melalui tiga aspek, yaitu:

1. Segi Kognitif atau Pengetahuan

Penerapan metode Small Group Discussion tidak hanya berpusat kepada dosen atau pendidik saja, melainkan mahasiswa yang akan menjadi centernya dalam pembelajaran di kelas. Dengan metode diskusi pengetahuan mahasiswa akan lebih meningkat, karena apabila mahasiswa hanya sekedar mendengarkan penjelasan dari dosen saja kemungkinan yang dapat dimengerti dengan baik hanya sedikit dan mudah hilang dari ingatan mahasiswa. Ketika proses pembelajaran dengan melibatkan mahasiswa dalam diskusi akan menambah daya ingat mahasiswa meningkat, hal itu dikarenakan mahasiswa dapat memahami bacaan kemudian mempresentasikannya.

2. Segi Afektif atau Sikap

Sikap mulia yang dapat dihasilkan melalui metode diskusi antara lain: saling menghargai pendapat orang lain, saling menghormati walaupun berbeda pandangan, saling toleran, menerima dengan lapang dada apabila ternyata pendapatnya salah, legowo untuk mengakui kesalahan diri sendiri dan menerima pendapat yang benar dari kelompok lain maupun dari pendidik.

Dalam pembentukan sikap ini, dosen juga memberikan contoh yang baik kepada mahasiswanya, misalnya dengan memberikan apresiasi pada tiap kelompok terhadap pendapat mereka serta pendidik mengajak untuk dapat mengkritisi apa yang telah disampaikan oleh kelompok lain dengan sopan. Hal yang demikian tersebut akan menciptakan suasana pembelajaran yang penuh rasa kekeluargaan dengan sikap dan etika yang baik di kelas.

Contoh dari Instrumen penilaian sikap yang dilakukan oleh dosen sebagai terwujudnya Small Group Discussion adalah sebagai berikut:

\begin{tabular}{|c|l|c|c|c|c|}
\hline \multirow{2}{*}{ No } & \multicolumn{1}{|c|}{ Aspek yang diamati } & \multicolumn{2}{|l|}{ Keterangan } \\
\hline & \multicolumn{1}{|c|}{ B } & C & K & \\
\hline 1 & Tingkat Perhatian terhadap materi di kelas & & & & \\
\hline 2 & Keaktifan dalam diskusi & & & & \\
\hline 3 & Tanggung jawab sesuai tugasnya & & & \\
\hline 4 & Menghargai pendapat orang lain & & & \\
\hline 5 & $\begin{array}{l}\text { Tingkat perhatian pada saat presentasi } \\
\text { oleh mahasiswa }\end{array}$ & & & \\
\hline
\end{tabular}


*Berilah tanda centang (v) pada kolom sesuai kriteria yang ditunjukkan mahasiswa

Rubrik penilaian:

Baik : Jika aspek atau kriteria yang diamati dengan nyata dan sesuai indicator aspek yang diamati (skor 3)

Cukup : Jika aspek atau kriteria yang diamati dengan cukup nyata dan cukup sesuai indicator aspek yang diamati (skor 2)

Kurang: Jika aspek atau kriteria yang diamati dengan kurang nyata dan kurang sesuai indicator aspek yang diamati (skor 1)

Nilai: $\frac{\text { skor perolehan }}{\text { skor maksimal }} \times 100$

\section{Keterangan:}
a. Nilai 91-100 berarti amat baik
b. Nilai $71-90$ berarti baik
c. Nilai 61-70 berarti cukup
d. Nilai kurang dari 60 berarti kurang

3. Psikomotorik / Keterampilan

Diskusi yang berlangsung menuntut mahasiswa untuk terampil dalam menggali materi dan memahami materi secara mendalam. Selain bisa terampil dalam menggali materi mahasiswa juga harus terampil dalam berbicara mengemukakan pendapatnya di depan mahasiswa lain dan mempertahankan pendapatnya. Sehingga dosen harus mampu membuat mahasiswa yang pendiam tersebut menjadi aktif dan kondusif.

Dari analisis di atas dapat kita lihat, bahwasanya pelaksanaan metode active learning mempengaruhi dalam peningkatkan keaktifan belajar mahasiswa semester 4 kelas D mata kuliah perkembangan peserta didik, sehingga mahsiswa aktif dalam kelas dan dapat memahami materi perkuliahan dengan metode yang menarik dan tidak membosankan.

Demikian hasil analisa penulis mengenai apakah dengan metode active learning dengan diskusi kelompok atau small group discussion dapat meningkatkan keaktifan belajar yang melibatkan mahasiswa semester 4 kelas 
D mata kuliah perkembangan peserta didik jurusan PAI FIAI UII Yogyakarta yang ditinjau dari teori-teori yang dikemukakan oleh para ahli.

Berdasarkan hasil observasi kegiatan yang mengintegrasikan pembelajaran active learning dengan metode SGD serta wawancara kepada 10 mahasiswa pada prodi PAI dapat diketahui beberapa faktor pendukung dan penghambat selama proses pembelajaran.

Faktor Pendukung dan Penghambat Pembelajaran active learning metode small group discussion Prodi PAI UII semester 4 mata kuliah Perkembangan Peserta Didik adalah sebagai berikut:

a. Faktor Pendukung Active learning-SGD

1) Mempertimbangkan strategi pembelajaran pada model active learning. Setiap strategi pada pembelajaran active learning memerlukan persiapan yang berbeda dalam pelaksanaannya. Oleh sebab itu, perlu dipertimbangkan dengan baik strategi yang akan digunakan. Beberapa hal yang dapat dijadikan pertimbangan dalam memilih strategi pembelajaran adalah melihat tujuan pembelajaran, melihat alokasi waktunya dan sarana prasarananya.

2) Memberikan arahan yang jelas.

Dikarenakan sebagian besar strategi dalam model pembelajaran active learning adalah kerjasama untuk berdiskusi dalam kelompok, maka diskusi dalam kelas merupakan tanggung jawab dosen untuk menjaganya dalam alur dan waktu yang baik, sehingga pengarahan yang jelas dapat mempengaruhi keberhasilan dalam setiap proses pembelajaran di dalam kelas.

3) Motivasi berperan penting dalam kegiatan pembelajaran.

Kegiatan pembelajaran active learning akan berhasil baik apabila mahasiswa memiliki motivasi yang tinggi dalam belajar. Selain itu, motivasi belajar yang tinggi akan mendorong mahasiswa untuk aktif berpartisipasi pada pembelajaran dalam setiap strategi dalam model active learning terutama dalam metode kelompok diskusi atau SGD agar mahasiswa dapat memperoleh hasil pembelajaran secara efektif dan optimal. 
4) Terdapat sarana dan prasarana yang memadai.

Dikarenakan kegiatan pembelajaran dilakukan melalui perangkat seperti laptop, LCD serta media pendukung lainnya yang sangat diperlukan.

b. Faktor Penghambat Active Learning-SGD

1) Waktu yang terbatas

konsep dasar dari pembelajaran active learning adalah segala bentuk pembelajaran yang memungkinkan mahasiswa berperan secara aktif dalam proses pembelajaran itu sendiri baik dalam bentuk interaksi antar mahasiswa maupun mahasiswa dengan dosen dalam proses pembelajaran tersebut. Sehingga, dibutuhkan waktu yang cukup panjang agar seluruh mahasiswa dapat berpartisipasi aktif.

2) Ketidaksiapan dari mahasiswa untuk menerima materi baru.

Pembelajaran active learning mempunyai konsekuensi kepada mahasiswa untuk dapat mempersiapkan diri dengan baik di luar jam kuliah

3) Didoominasi mahasiswa yang pintar.

Pembelajaran active learning ditujukan agar mahasiswa secara aktif bertanya dan menyatakan pendapat dengan aktif selama proses pembelajaran, sehingga saat berdiskusi kelompok nampak hanya beberapa mahasiswa yang mendominasi untuk aktif menyatakan pendapat.

\section{KESIMPULAN}

1. Pembelajaran mata kuliah perkembangan peserta didik dengan metode active learning yaitu small group discussion berpengaruh terhadap peningkatan keaktifan belajar yang melibatkan mahasiswa semester 4 kelas D mata kuliah perkembangan peserta didik jurusan PAI FIAI UII Yogyakarta. Hal tersebut terbukti dengan keterlibatan mahasiswa yang pasif di dalam proses pembelajaran sehingga menjadikan mereka aktif dalam berdiskusi dengan teman yang lain. 
2. Dosen mata kuliah perkembangan pserta didik menganggap strategi pembelajaran active learning dengan metode diskusi kelompok adalah yang paling cocok diterapkan pada mahasiswa untuk belajar secara aktif secara efektif dan efisien, sehingga menjadikan dosen tidak banyak memberikan materi, hanya saja memberikan penguatan.

\section{DAFTAR PUSTAKA}

Abdurrahman. 2017. Efektivitas dan Kendala Pembelajaran Sains Berbasis Inkuiri terbadap Capaian Dimensi Kognitif Siswa : Meta Analisis. Tadris: Jurnal Keguruan Dan Ilmu Tarbiyah.

Bahri, Syaiful Djamrah, dan Aswan Zain, 2006. Strategi Belajr Mengajar, Jakarta: Rineka Cipta.

Ismail. 2011. Strategi Pembelajaran Agama Islam Berbasis PAIKEM, Semarang:Rasail.

Mardiah Kalsum Nasution, 2017. "Penggunaan Metode Pembelajaran Dalam Peningkatan Hasil Belajar Siswa", dalam Jurnal Ilmiah Bidang Pendidikan, Vol. 11 No. 1.

Muhtadi, Ali dalam artikel yang berjudul Model Pembelajaran "Active Learning" dengan

Metode Kelompok untuk. Meningkatkan Kualitas Proses Pembelajaran di Perguruan Tinggi,

Mujiono, Dimyati. 2013. belajar dan pembelajaran, Jakarta: PT. Rineka cipta.

Munir. 2008. Kurikulum Berbasis Teknologi Informasi dan Komunikasi, Bandung: Alfabeta.

Nurdyansyah \& Eni Faiyatul Fahyuni, 2016. Inovasi Model Pembelajaran Sesuai Kurikulum 2013, Sidoarjo: Nizamia Learning Center Sidoarjo.

Nur Wahyuning Sulistyowati, 2016. "Implementasi Small Group Discussion Dan Collaborative Learning Untuk Meningkatkan Prestasi Belajar Mahasiswa Program Studi Pendidikan Akuntasi IKIP PGRI Madiun”, dalam Jurnal Akuntasi dan Pendidikan, Vol. 5 (2).

Rohani, Ahmad . 2010. Pengelolahan pengajaran, Jakarta: PT Rineka cipta.

Sohibun, Febriani, \& Maisaroh, 2017. Peranan Mata Kuliah Profesi Kependidikan dan Microteaching terbadap Kompetensi Profesional Mahasiswa PPL Fisika. Tadris: Jurnal Keguruan Dan Ilmu Tarbiyah.

Sudjana, Nana. 2005. Metode Statistika, Edisi Ke 6, Bandung: Tarsito. 